Check for updates

Montreal

Cite this as: BMJ 2021;374:n1815 http://dx.doi.org/10.1136/bmj.n1815 Published: 16 July 2021

\title{
Covid-19: Indonesia becomes Asia's new pandemic epicentre as delta variant spreads
}

\section{Owen Dyer}

The delta variant of covid-19 is causing an escalating crisis in Indonesia, two months after it swept through India. Indonesia's case numbers have risen sharply for the past month and are continuing to do so. But its plight may only be the forerunner of a broader wave in Asia, as the variant has been found across the region in recent days.

Cases are rising fast in Bangladesh, Iran, Iraq, Japan, Kazakhstan, Malaysia, Myanmar, Pakistan, South Korea, Thailand, and Vietnam. Among these countries, the most immunised is Japan, with just $17.9 \%$ of the population fully vaccinated.

Indonesia, which has fully vaccinated $5.5 \%$ of its citizens, has reported an average 919 deaths a day over the past week. In per capita terms, this is the same as the peak death rate reported by India in mid-May-3.32 deaths per million people per day.

The pandemic's worst reported daily deaths per capita-in Hungary and Peru in April, and in Namibia currently-are nearly 10 times higher. But it is thought that Indonesia's official figure of 70152 deaths describes, as in India, the tip of a hidden iceberg. And with case numbers more than doubling in the past two weeks and still rising, Indonesia's death rate is set to climb further.

The depth of India's covid crisis was signalled by the smoke of countless cremations. But in Indonesia the dead are buried in cemeteries provided by the government, the rapid growth of which is visible from the air. ${ }^{1}$ Teams of civilian volunteers have formed to help take away the bodies of people who died isolating at home.

Indonesia detected 56767 new cases on 15 July, but its test positivity rate has soared to $26 \%$, suggesting that large numbers of cases are being missed. A serology survey by the Indonesian Centres for Disease Control, conducted in late March and published on 9 July, found covid-19 antibodies in $44.5 \%$ of Jakarta residents, suggesting that 4.7 million of the city's 10.6 million inhabitants had been exposed to some form of the virus. A third of those with antibodies remembered having symptoms, but only $8 \%$ of them were ever diagnosed. ${ }^{2}$

Indonesia donated oxygen supplies to India in May but is now facing shortages itself. At the Sardjito hospital in Java, 63 covid patients died in one day, 33 of them after its central oxygen supply ran out. The country has lost more than 400 doctors to the pandemic, according to the Indonesian Medical Association, including at least 20 who were fully vaccinated with Sinovac.

While Indonesia is reporting the world's highest absolute number of new cases, its trajectory is mirrored on a lesser scale in many Asian countries. South Korea has seen daily case numbers double in the past week, as have Kazakhstan and Vietnam. Few countries have kept the virus at bay more successfully than Vietnam, but the delta variant has gained a foothold and just $0.3 \%$ of the population are fully vaccinated.

In Pakistan, which was spared the very worst of the pandemic until now, the government told citizens to expect a difficult fourth wave, as cases jumped sharply on 15 July. "The delta variant has caused devastation in countries in the region," warned minister for planning Asad Umar. Sindh province reimposed restrictions as the test positivity rate in Karachi reached $19.3 \%$, with the Eid al-Adha religious festival days away.

In Iran, President Rouhani said that the country is entering its fifth wave, less than three months after its last major spike in deaths. In Myanmar, soaring case numbers are compounded by a political crisis as both doctors and patients shun hospitals that in many cases have been occupied by the military.

On 15 July, the delta variant appeared for the first time in the Kurdish Autonomous Zone of Iraq. Only $1 \%$ of Iraqis are fully vaccinated against the coronavirus.

1 Lamb K, Widianto S. Aerial images of expanding graves capture Indonesia's
deadliest days. Reuters. 8 July 2021. www.reuters.com/world/asia-pacif-
ic/aerial-images-expanding-graves-capture-indonesias-deadliest-days-
2021-07-08.
2 Jakarta nears herd immunity as half of its population have had covid-19:
survey. Jakarta Globe. 11 July 2021. https://jakartaglobe.id/news/jakarta-
nears-herd-immunity-as-half-of-its-population-have-had-covid19-survey.

This article is made freely available for use in accordance with BMJ's website terms and conditions for the duration of the covid-19 pandemic or until otherwise determined by BMJ. You may use, download and print the article for any lawful, non-commercial purpose (including text and data mining) provided that all copyright notices and trade marks are retained. 